\title{
Merytoryczne, psychopedagogiczne i dydaktyczne aspekty kształcenia nauczycieli języków obcych. Rozważania teoretyczne $\mathrm{z}$ aneksem empirycznym
}

\author{
Substantive, psycho-pedagogical and didactic aspects \\ of foreign language teacher education. \\ Theoretical considerations with an empirical extension
}

Zdzisław ALEKSANDER ${ }^{1}$

Ateneum-Szkoła Wyższa w Gdańsku

\begin{abstract}
When looking at the relationship between substantive education and the pedagogical background of a teacher (foreign language teacher included) there has been an eternal disagreement both in the academia, as well as among prospective employers. The most essential controversy pertains to the degree of expertise a teacher should possess in the field they teach versus how much psycho-pedagogical and educational knowledge they should have and the mutual relationship of the two. Another area of dispute and debate within the teachers' education specialism seems to occur between two parties: proponents of theoretical research and the narrow circle of practical education advocates. The empirical annex, which points to the level of vocational preparation of a language teacher, focuses on the choice of didactic activities, the quality of their execution, and the working conditions which are under a teacher's control.
\end{abstract}

Keywords: foreign language teacher, psycho-pedagogical competence, teachers' training

1 https://orcid.org/0000-0002-4281-7890. 


\section{Streszczenie}

W poglądach na kształcenie nauczycieli, także nauczycieli języków obcych, zarówno w środowisku akademickim jak i wśród potencjalnych pracodawców, od lat nie ma zgodności co do relacji między kształceniem merytorycznym (filologicznym), a przygotowaniem pedagogicznym. Zasadnicza kontrowersja dotyczy tego, na ile nauczyciel powinien być specjalistą $\mathrm{w}$ zakresie nauczanego przedmiotu, na ile zaś powinien opanować wiedzę psychopedagogiczno-metodyczną oraz jakie są relacje między wiedzą specjalistyczną i pedagogiczną a umiejętnościami zawodowymi nauczyciela. Inny obszar sporów i dyskusji dotyczącej kształcenia nauczycieli odbywa się między zwolennikami studiów teoretycznych, a rzecznikami kształcenia wąsko praktycznego. W artykule w oparciu publikacje naukowe, rozporządzenia ministerialne i raporty z badań prezentowane są te stanowiska i argumenty ich zwolenników. W aneksie empirycznym dotyczącym poziomu przygotowania zawodowego nauczycieli języków obcych skupiono się na doborze czynności dydaktycznych, na jakości ich wykonania i na warunkach pracy na lekcji zależnych od nauczyciela.

Słowa kluczowe: nauczyciel języka obcego, psychopedagogiczne kompetencje, kształcenie nauczycieli

\section{Aspekty teoretyczne problemu}

W poglądach na kształcenie nauczycieli, także nauczycieli języków obcych, zarówno w środowisku akademickim jak i wśród potencjalnych pracodawców od lat nie ma zgodności co do relacji między kształceniem merytorycznym (filologicznym) a przygotowaniem pedagogicznym $\mathrm{w}$ postaci wiedzy psychologiczno-pedagogicznej i dydaktycznej oraz umiejętności praktycznych. Spór dotyczy także roli wiedzy i umiejętności oraz przygotowania przyszłych nauczycieli $\mathrm{w}$ zakresie treści społecznych i dbałości o ich ogólny rozwój. Pierwszy z tych aspektów wymaga znajomości problematyki filozoficznej, zagadnień ekologicznych, ekonomicznych i politycznych współczesnego świata. Drugi dotyczy rozwoju specjalnych zainteresowań. Znajomość i przeżywanie różnych dziedzin sztuki - to podstawowy kierunek poczynań w tej dziedzinie² (Rutkowiak, 1986).

Jednakże zasadnicza kontrowersja dotyczy tego, na ile nauczyciel powinien być specjalistą $\mathrm{w}$ zakresie nauczanego przedmiotu, na ile zaś powinien opanować wiedzę psychopedagogiczno-metodyczną. Uważa się, że skupianie się na kształceniu merytorycznym (filologicznym) może prowadzić do negatywnych konsekwencji w pracy pedagogicznej. Z drugiej zaś strony nie może być wątpliwości, że zbytnie obniżanie poziomu kształcenia

\footnotetext{
2 Szczegółowy przegląd koncepcji kształcenia nauczycieli (m.in. pragmatycznej, scjentystycznej, humanistycznej) dyskutowanych w końcu XX wieku, patrz: Rutkowiak (1986).
} 
merytorycznego może prowadzić do ogólnikowości i dyletantyzmu. Przygotowanie takie (zwłaszcza w aspekcie sprawności językowych) powinno być więc jak najlepsze ${ }^{3}$ (Siemak-Tylikowska, Kwiatkowska, Kwiatkowski, 1998, Zawadzka, 2004).

Jak słusznie stwierdza T. Kotarbiński (1970) pedagogów różni to, czego są nauczycielami (języka, fizyki, historii), ale łączy fakt, że są nauczycielami. To stanowi ich specjalizację zawodową, wspólną i łączną. Wynika z tego, że myśląc o kształceniu nauczycieli, należy uwzględnić zarówno cechy ogólne, charakterystyczne dla całego zawodu jak i te, które ten zawód różnicują (chodzi tu głównie o różnice wynikające ze specjalizacji przedmiotowej).

Kształcenie w zakresie dyscypliny kierunkowej stanowi zawsze istotę studiów nauczycielskich. Powstaje jednak problem, jak racjonalnie skojarzyć punkt widzenia tej dyscypliny, zasób jej podstawowych pojęć z wymaganiami programów kształcenia. Badacze tego zagadnienia wyrażają pogląd, że opanowanie struktury dyscypliny kierunkowej musi być na tyle głębokie i wszechstronne, by pozwoliło nauczycielowi swobodnie operować programem i wychodzić poza przewidziane w nim treści ${ }^{4}$ (Rutkowiak, 1994).

Nauczyciel na każdym stopniu kształcenia staje wobec konieczności wyboru określonych zespołów informacji naukowej dla celów przekazu szkolnego. Wynika z tego, że studiowaną dyscyplinę należałoby rozpatrywać $\mathrm{z}$ punku widzenia jej struktury, podstawowych pojęć, ale także $\mathrm{z}$ punktu widzenia kształcenia szkolnego (uwzględniać np. te rodzaje operacji intelektualnych, które występują $\mathrm{w}$ działalności szkolnej nauczyciela i uczniów).

Przykładem mogą tu być wykłady, ćwiczenia czy seminaria z zakresu historii literatury na kierunkach filologicznych. W programach tych zajęć mogłoby znaleźć się miejsce na materiał, występujący $\mathrm{w}$ programach i podręcznikach szkolnych, a szczególnie na te rodzaje analizy historycznoliterackiej, które mogą. być przedmiotem pracy dydaktycznej.

Chodziłoby tu głownie o metodologiczne studia $\mathrm{z}$ zakresu danej dyscypliny naukowej (tu o aspekty metodologii historycznoliterackiej), a nie o szczegółowe wskazówki metodyczne. Przygotowanie metodologiczne (w zakresie językoznawstwa czy teorii literatury) może być jednocześnie

\footnotetext{
${ }^{3}$ Zróżnicowanie bardziej współczesnych poglądów na kształcenie nauczycieli w perspektywie wymagań zmieniającego się świata pokazuje zbiór tekstów: Siemak-Tylikowska, Kwiatkowska, Kwiatkowski (1998), a także: Zawadzka (2004).

${ }^{4}$ Zob. anglojęzyczne opracowanie: Teacher training - between atomism and holism (Rutkowiak, 1994).
} 
ważnym elementem przygotowania zawodowego nauczyciela języka obcego. Kultura metodologiczna nauczyciela może sprzyjać stwarzaniu uczniom okazji do samodzielnych działań intelektualnych (Komorowska, 2015, Orchowska 2010).

Omawiany tu problem dotyczący przygotowania merytorycznego i pedagogicznego nauczycieli $\mathrm{w}$ ostatnim czasie stał się przedmiotem zainteresowania różnych gremiów za sprawą reformy szkolnictwa i reformy związanej z kształceniem nauczycieli. Przykładem może być raport opracowany przez Zespół roboczy do spraw kształcenia nauczycieli RGNiSzW, w którym krytykuje się stosowane ma uczelniach praktyki, gdzie podstawę przygotowania merytorycznego kandydatów na nauczycieli stanowią przedmioty kierunkowe (filologiczne), a podstawę przygotowania pedagogicznego - przedmioty psychopedagogiczne, metodyka nauczania i praktyka. Zwraca się uwagę, iż organizacja pracy dydaktycznej odnosi się nie tylko do zewnętrznych przejawów pracy nauczyciela, ale także do aspektów merytorycznych dotyczących nauczania języków obcych (językoznawczych, literaturoznawczych, kulturoznawczych). Oba aspekty lekcji - merytoryczny i dydaktyczny - nie mogą być traktowane jako odrębne, czy wręcz sobie przeciwstawne (Łaszczyk 2018).

Zwraca się także uwagę, że trakcie studiów treści wykładane na przedmiotach kierunkowych traktowane są wyłącznie jako materiał do opanowania przez studenta. Jest on ukierunkowany na percepcję materiału, a nie na jego transformację i transpozycję. Dydaktyka $\mathrm{z}$ kolei eksponuje czynnik organizacyjny, skupiając się na formach, metodach i środkach nauczania i uczenia się. Inaczej mówiąc, to, co jest najbardziej istotne dla praktyki nauczania przedmiotu, w dydaktyce szkoły wyższej często znajduje się poza polem widzenia przedmiotów kierunkowych, jak i pedagogicznych. Efektywność pracy nauczyciela pozostaje w ścisłym związku $\mathrm{z}$ ukierunkowaniem jego wiedzy merytorycznej na pracę w szkole. Oznacza to, że przygotowanie do zawodu należałoby traktować kompleksowo, a nie zaczynać go od określonego momentu (np. z chwilą rozpoczęcia studiowania przedmiotów psychopedagogicznych) (Gołębniak, Krzychała, 2015, Gołębniak, Zamorska, 2014, Łaszczyk, 2018).

Tendencją, która zaczyna dominować, jest ciągłość i równoległość kształcenia teoretycznego i praktycznego. Koncepcja zintegrowanego kształcenia teoretycznego i praktycznego w przypadku kształcenia nauczycieli języków obcych może być realizowana w trzech następujących etapach: 1) okres kształcenia wrażliwości i spostrzegawczości dydaktycznometodycznej, 2) okres opanowania metod i technik nauczania, 3) okres 
samodzielnych działań pedagogicznych. Jak trafnie zauważa H. Komorowska (Komorowska, 1987, Komorowska, 2014) zachowanie równowagi między tymi trzema komponentami procesu kształceniu nauczycieli wydaje się koniecznością.

Dodajmy, że w najnowszym Standardzie kształcenia nauczycieli zawartym w Rozporządzeniu MNiSW55 (Dz.U. 2019, Poz. 1450) mówi się o takim kształceniu merytorycznym, które przygotowuje do nauczania przedmiotu szkolnego. W kształceniu psychologiczno-pedagogicznym podkreślono konieczność integracji treści realizowanych na zajęciach audytoryjnych z praktyką pedagogiczną, a w przygotowaniu dydaktycznometodycznym zaleca się uwzględnianie specyfiki przedmiotu ( $\mathrm{w}$ naszym przypadku będzie to specyfika nauczania języków obcych).

Przejdźmy teraz do jeszcze innego obszaru dyskusji i sporów dotyczących kształcenia nauczycieli, jakie odbywają się między zwolennikami studiów teoretycznych, a rzecznikami kształcenia wąsko praktycznego, niekiedy wręcz algorytmicznego. Wychodząc z koncepcji kształcenia teoretycznego akcentuje się pogląd, iż opanowanie zespołu dyscyplin naukowych powinno być na tyle wystarczające, by pozwoliło nauczycielowi rozstrzygać problemy i wykonywać zadania zawodowe. Rzecznicy kształcenia praktycznego uważają, że w kształceniu nauczycieli istotne jest tylko to, co ma praktyczne zastosowanie w pracy pedagogicznej. W przypadku kształcenia nauczycieli języków obcych byłyby to przede wszystkim kompetencje językowe (komunikacyjne) i umiejętności dydaktyczno-metodyczne. $\mathrm{Z}$ takim stanowiskiem można spotkać się nawet w czasie wystąpię na konferencjach naukowych ${ }^{6}$.

Kandydat na nauczyciela powinien posiadać pewne umiejętności postpowania z uczniami. Jednak umiejętność postpowania nie jest wartością wyłącznie intelektualną i należałoby zapoznawać studentów z pewnymi schematami działań dydaktycznych, co może zapobiegać popełnianiu najbardziej elementarnych błędów. Warto w tym miejscu przywołać

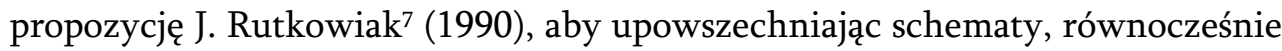

\footnotetext{
${ }^{5}$ Rozporządzenie Ministra Nauki i Szkolnictwa Wyższego z dnia 25 lipca 2019 r. w sprawie standardu kształcenia przygotowującego do wykonywania zawodu nauczyciela, Zał. nr 1, Dz.U. 2019, Poz.1450.

${ }^{6}$ Przykładem może tu być dyskusja, jaka odbyła się na Konferencji Naukowej nt. Szkice do portretu nauczyciela w latach PRL-u, UG, kwiecień 2012, w toku której proponowano powrót do modelu kształcenia nauczycieli, jaki realizowano w liceach pedagogicznych w XX wieku (było to kształcenie wąsko praktyczne, wręcz algorytmiczne).

7 W kontekście aspektów I źródeł profesjonalnej refleksji nauczyciela zob. także: CzerepaniakWalczak (1997).
} 
wskazywać ich słabe strony i pomagać je przezwyciężać. Schemat i wzór do naśladowania mogą stanowić tylko doraźną formę przygotowania do zawodu, od której trzeba odchodzić, zanim stanie się podstawą działań rutynowych. Porady praktyczne, przykładowe rozwiązania jednostkowych, dokładnie określonych zadań, przepisy i szczegółowe wyposażanie nauczycieli we wskazówki typu algorytmicznego sprzyjają zrachowaniom przystosowawczym. Uniemożliwiają zaś przetwarzanie informacji i nie ułatwiają przezwyciężania kontekstów sytuacyjnych (nauczycielskie reakcje uzależnione są wówczas jedynie od znanych sytuacji). Pedagoga, zaprogramowanego na odbiór gotowych receptur i wzorów, na ich przyswajanie i naśladowanie, będzie charakteryzowano działanie o niskim poziomie refleksyjności, sztywność i bezradność, gdy zawiodą go znane wzorce. Takie akoncepcyjne wykonawstwo pozostaje $\mathrm{w}$ wewnętrznym konflikcie $\mathrm{z}$ naturalną dynamiką „materii dydaktycznej”. Słabość tego modelu przygotowania nauczycieli wynika z empirycznego faktu nieistnienia jednakowych sytuacji dydaktycznych. Jest to spowodowane wielością i różnorodnością elementów, które te sytuacje określają.

Wspomniana wyżej Autorka proponuje przygotowania nauczycieli, polegające na przekazywaniu przede wszystkim treści typu heurystycznego, a nie jednostkowych treści tematycznych. Taka informacja ogólna ma służyć rozumieniu zjawisk przez ich wyjaśnianie przyczynowe, genetyczne i funkcjonalne. Interpretacja faktów szczegółowych poprzez zasady ogólne może sprzyjać temu, aby w przyszłości kandydat na nauczyciela wytwarzał nowe programy czynności lub modyfikował dotychczas poznane. Chodzi tu o stymulowanie, o naprowadzanie na poszukiwanie rozwiązań poprzez własne kreatywne wysiłki. Przyszły nauczyciel byłby przy takim podejściu stawiany w sytuacji przetwarzania i wytwarzania informacji, wykonywałby czynności typowe dla rozwiązywania problemów. Podczas gdy w praktycystycznym modelu kształcenia nastawiony on jest na zapamiętywanie i odtwarzanie informacji i wzorów działania.

Warto także zwrócić uwagę na kolejny wątek dyskutowany w kontekście kształcenia nauczycieli (także nauczycieli języków obcych), mianowicie na wzajemne relacje między wiedzą specjalistyczna oraz szeroko rozumianą wiedzą pedagogiczną nauczyciela a jego umiejętnościami zawodowymi (Balażak, 2009, Kawecki, 2013, Król, Pielachowski, 1995, Strykowski, 2005).

Należy przychylić się do poglądu, iż wiadomości nie powinny być przeciwstawiane umiejętnościom, które są czynnościami o określonych właściwościach. Wiadomości bowiem są ich częścią składową. Wiedzieć - to znaczy wykonywać jakieś działanie lub czynność związaną $\mathrm{z}$ tymi 
umiejętnościami. Tak więc, gdy mówimy: „umiejętności zawodowe”, rozumiemy tym samym wiedzę warunkującą poprawne wykonywanie tych umiejętności. Ten bowiem, kto posiada umiejętności, posiada i wiedzę, bez której nie mógłby ich opanować. Sytuacji tej nie można odwrócić, gdyż opanowanie wiedzy nie musi automatycznie pociągać powstawania umiejętności. Wiedza najczęściej jednak odgrywa rolę czynnika pierwotnego (Jakóbowski 1982).

Problem staje się tym bardziej istotny, gdy uwzględnimy fakt, że w zawodzie nauczycielskim poczatkujący nauczyciel nie może być "stażystą", nie może otrzymywać zadań łatwiejszych ze względu na brak kompetencji zawodowych. Od pierwszych godzin pracy nie może popełniać błędów, których niewymierne skutki ponosiliby jego uczniowie.

Kolejny wątek, który nie znajduje jednomyślnego rozstrzygnięcia, to związek dydaktyki szczegółowej (metodyki) z pedagogiką jako dyscypliną i z dyscypliną kierunkową (neofilologią). Główny punkt sporny to status naukowy dydaktyki szczegółowej, jej samodzielność. Specjaliści neofilolodzy uważają, że dydaktyka języków obcych wyodrębniając swoje pole badawcze i wypracowując warsztat metodologiczny zyskała status dziedziny naukowej i stała się zdolna do stworzenia optymalnego modelu nauczania języka (Komorowska, 1982, 2014, 2015, 2017). Dyscypliny filologiczne (językoznawstwo, literaturoznawstwo) oraz pedagogika i dyscypliny im pokrewne (filozofia, psychologia, nauki o kulturze, nauki socjologiczne) dostarczają informacji wchodzących w zakres dydaktyki języków obcych (Gałązka, 2013).

Zajmijmy się w tym miejscu adaptacją treści z zakresu dydaktyki ogólnej $\mathrm{w}$ pracy zawodowej nauczyciela języków obcych. Problem ten może być rozpatrywany przynajmniej w dwóch aspektach: jako wpływ na osobowość i kulturę dydaktyczną, bądź jako bezpośrednie oddziaływanie na czynności związane $\mathrm{z}$ nauczaniem. W pierwszym przypadku chodzi $\mathrm{m}$. in. o rozumienie założeń programowych, budzenie głębszej refleksji nad celami własnej pracy zawodowej, określanie ważności poszczególnych zagadnień dydaktycznych, rozwijanie samodzielności i zainteresowań naukowych. W drugim - np. o trafny dobór form organizacyjnych na zajęciach (praca indywidualna, grupowa bądź zbiorowa), o dobór adekwatnych do celów środków kształcenia, czy o poszukiwanie $\mathrm{z}$ własnej inicjatywy doskonalszych form i metod nauczania języków (Rutkowiak, 1990).

Jeszcze inaczej rzecz ujmując efekty kształcenia w zakresie dydaktyki ogólnej mogą służyć nauczycielowi jako: 1) źródło nowych wzorów $\mathrm{w}$ postępowaniu dydaktycznym, 2) bezpośrednia pomoc $\mathrm{w}$ zrozumieniu 
sytuacji dydaktycznych spotykanych $\mathrm{w}$ czasie pracy, 3) materiał do analiz czynności dydaktyczno-wychowawczych i planowania własnej pracy zawodowej, 4) źródło inspiracji do unowocześniania form i metod działania zawodowego.

Podstawowym elementem procesu dydaktycznego i główną, choć nie jedyną, formą działalności nauczyciela jest lekcja. Wszystkie najważniejsze zadania dydaktyczne związane z opanowaniem wiedzy i umiejętności, a także wartości moralnych, wartości kulturowych, realizowane są na lekcji, w toku pracy audytoryjnej. Lekcja jest także tą formą procesu dydaktycznego w trakcie której weryfikuje się, doskonali, modyfikuje (względnie odrzuca) poznane w czasie studiów i w procesie samokształcenia koncepcje i szczegółowe rozwiązania. Poprzez lekcje koryguje się programy nauczania oraz dokumenty o charakterze instruktażowym i dyrektywnym, weryfikuje się jakość oraz przydatność podręczników i środków dydaktycznych. Wynika z tego, że wiele uwag dotyczących lekcji jako formy zorganizowanego działania dydaktycznego, może odnosić się także do innych form pracy nauczyciela (Sylwestrowicz, 1985).

\section{Aneks empiryczny}

W kontekście powyższych rozważań można przyjąć, że jakość prowadzonych przez nauczyciela lekcji, może odzwierciedlać jakość [poziom] jego przygotowania zawodowego. Obserwacja lekcji może być źródłem wiedzy o ewentualnych niedoskonałościach tego przygotowania i być źródłem inspiracji do wprowadzenia korekt lub zmian w kształceniu i doskonaleniu nauczycieli języków obcych.

Dlatego powyższe rozważania chciałbym uzupełnić aneksem empirycznym w postaci wyników obserwacji lekcji języków obcych przeprowadzonych przez słuchaczy studiów podyplomowych ${ }^{8}$.

Przedstawiając niektóre wyniki obserwacji skupimy uwagę na trzech podstawowych elementach decydujących o wartości lekcji i uwidaczniających

\footnotetext{
8 Zaprezentowane tu dane empiryczne są rezultatem analizy prac dyplomowych, które tworzone były z wykorzystaniem materiału badawczego uzyskanego metodą obserwacji w trakcie praktyk pedagogicznych. Celem tych obserwacji było zebranie materiału empirycznego do prac dyplomowych. Osoby prowadzące obserwacje (hospitujący lekcje języków obcych) posiadały przygotowanie pedagogiczne i poprzez studia podyplomowe w ATENEUM-Szkole Wyższej zdobywali kwalifikacje do nauczania kolejnego przedmiotu lub podwyższali swoje kwalifikacje zawodowe. Do jakościowej analizy wybrano 20 prac dyplomowych (powstały w latach 20142018), które zawierały prezentowane w tym opracowaniu dane empiryczne.
} 
poziom przygotowania zawodowego nauczyciel języka obcego, a mianowicie na doborze czynności dydaktycznych, na jakości ich wykonania i na warunkach pracy na lekcji zależnych od nauczyciela.

\subsection{Dobór czynności dydaktycznych}

Z doborem czynności dydaktycznych w określonym momencie (ogniwie) lekcji łączy się pojęcie koncepcji metodycznej lekcji. W przypadku niewłaściwego doboru czynności mówi się o błędach metodycznych. Analiza doboru czynności na lekcji (jak również ocena jakości ich wykonania) dotyczyła poszczególnych jej standardowych ogniw.

Analiza doboru czynności dydaktycznych w poszczególnych częściach lekcji pokazała, że błędy metodyczne odnotowano w trakcie znaczącej liczby analizowanych lekcji. Zwrócimy tu uwagę tylko na te zagadnienia, które mogą łączyć się z koniecznością posiadania przez nauczycieli wystarczającej wiedzy psychopedagogicznej i umiejętności metodycznych. Braki lub niedoskonałości kształcenia w wymienionym zakresie mogły skutkować uchybieniami w doborze czynności dydaktycznych. Wymienić tu należy:

1. Brak tak istotnego ogniwa lekcji, jakim jest zapoznanie uczniów $\mathrm{z}$ tematem i celami pracy na lekcji.

2. Brak koniecznych zabiegów metodycznych lub niewłaściwa kolejność czynności w poszczególnych ogniwach lekcji. Przykłady:

- brak ukierunkowania uczniów przed określoną formą pracy (np. przez słuchaniem nagrania, czy oglądaniem materiału filmowego),

- brak czynności dydaktycznych umożliwiających uczniom poprawne wykonanie zadania (np. tworzenie charakterystyki bohatera tekstu bez zgromadzenia i utrwalenia potrzebnej do tego leksyki),

- brak podsumowania i kontroli umożliwiającej zorientowanie się w stopniu opanowania wprowadzonego oraz utrwalanego materiału językowego, pozwalającej także wskazać uczniom na efekty ich pracy nad opanowaniem ćwiczonych na danej lekcji sprawności językowych,

- gromadzenie potrzebnej leksyki oraz przeprowadzenie koniecznych ćwiczeń leksykalnych i fonetycznych dopiero po niepowodzeniu w opowiadaniu przez uczniów treści obrazka,

- nieuzasadnione przerywanie czynności przed doporowadzeniem jej końca - przechodzenie do następnego punku lekcji, gdy poprzednia 
czynność sprawiała uczniom trudności lub nie przyniosła rezultatu (brak umiejętności modyfikacyjnych nauczyciela),

- zbyt długie wykonywanie czynności (imitacyjnego ćwiczenia fonetycznego), doprowadzające do znużenia i osłabienia koncentracji uczniów),

- zadawanie pracy domowej przekraczającej możliwości uczniów będącej przerzucaniem pracy zaplanowanej i nie wykonanej na lekcji na ich barki, np. zawierającej materiał językowy nie utrwalony na lekcji (pamięciowe opanowanie tekstu piosenki, pomimo że w czasie czytania w klasie dzieci popełniały znaczące błędy fonetyczne).

Należy dodać, że praca domowa była obecna na większości obserwowanych lekcji, a sam proces jej zadawania i kontroli nie był wolny od błędów metodycznych.

\subsection{Jakość wykonywanych czynności i warunki pracy zależne od nauczyciela}

Należy tu od razu stwierdzić, że analizując jakość wykonywanych czynności dydaktycznych, uwzględniono organizowanie i kierowanie pracą uczniów, normowanie współpracy $\mathrm{z}$ uczniami, stosunek nauczyciela do uczniów wynikający z jego wiedzy o psychice i rozwoju uczniów w określonym wieku, a także błędy językowe $\mathrm{i}$ rzeczowe (związane $\mathrm{z}$ treściami kształcenia językowego). Błędy językowe i rzeczowe popełniane przez nauczycieli uważamy za ważny problem w działalności zawodowej nauczycieli języków obcych, pomijamy go jednak w tym miejscu, gdyż wymagają one specjalistycznej, szczegółowej analizy i osobnego opracowania.

Zastrzeżenia dotyczące jakości czynności dydaktycznych pojawiały się we wszystkich ogniwach obserwowanych lekcji. Wśród nich wyróżnić można:

1. Nieprawidłowości związane $\mathrm{z}$ wprowadzaniem i objaśnianiem nowej leksyki, materiału gramatycznego i ortograficznego np.:

- brak wyraźnego rozróżnienia leksyki czynnej i biernej w pracy nad sprawnością mówienia,

- uporczywe trzymanie się zasady beztłumaczeniowej semantyzacji leksyki, mimo zdecydowanego braku rezultatów,

- objaśnianie uczniom szkoły podstawowej zjawiska gramatycznego w języku obcym, co przekraczało ich możliwości percepcyjne.

2. Błędy w czasie utrwalania wprowadzonego materiału językowego, np.: 
- niezwracanie uwagi na jakość wypowiedzi uczniów i na popełniane przez nich błędy,

- niewystarczająca ilość przykładów w serii ćwiczeń utrwalających, mało urozmaicony, powodujący znużenie uczniów przebieg ćwiczeń analitycznych w czytaniu.

3. Nieprawidłowości związane z kontrolą i oceną pracy uczniów, np.:

- brak jawności lub/i umotywowania oceny,

- manipulowanie oceną: wystawianie ocen dla postrachu, w celu uspokojenia klasy, dla ukarania uczniów spóźniających się na lekcję („uczenie punktualności”).

4. Uchybienia związane $\mathrm{z}$ organizowaniem i kierowaniem pracą uczniów, np.:

- praca z częścią klasy (część uczniów w danym momencie lekcji pozostawała bez zajęcia),

- niepoprawne organizowanie czynności dydaktycznych (wykonywanie dwóch czynności jednocześnie, np. cichego czytania i słuchania nauczyciela objaśniającego leksykę),

- brak reakcji nauczyciela na znudzenie klasy daną formą pracy,

- zachowanie nauczyciela powodujące zakłócenia w pracy uczniów (np.: rozmowy przez telefon komórkowy, nerwowe chodzenie po klasie).

5. Nieprawidłowości w układaniu i normowaniu współpracy z uczniami, np.:

- przerzucanie odpowiedzialności na uczniów w przypadku niepowodzenia dydaktycznego, wyrażanie zdziwieni i oburzenia w sytuacji, gdy uczniowie proszą o wyjaśnienie problemu, który zdaniem nauczyciela powinni znać,

- niewłaściwa reakcja nauczyciela w konkretnej sytuacji (ironizowanie w przypadku błędnych odpowiedzi uczniów, nieumiejętne rozwiązanie sytuacji konfliktowej),

- niepoprawny stosunek nauczyciela do uczniów - niegrzeczny, lekceważący,

- okazywanie zdenerwowania w sytuacji, gdy klasa jest bierna $\mathrm{z}$ powodu zmęczenia i przepracowania (lekcje $\mathrm{w}$ godzinach popołudniowych),

- reagowanie ironią na wzruszenie uczennicy,

- stawianie infantylnych, nie dostosowanych do poziomu uczniów problemów jako tematów konwersacji (uczniowie klasy licealnej). 


\section{Podsumowanie}

Zasygnalizowane tu zagadnienia zawiązane z doborem czynności i jakością ich wykonania, z organizowaniem i kierowaniem pracą uczniów oraz z układaniem sobie i normowaniem współpracy z uczniami wymagają określonego zakresu wiedzy i umiejętności z zakresu pedagogiki i jej subdyscyplin (szczególnie dydaktyki ogólnej), psychologii i jej subdyscyplin (szczególnie psychologii rozwojowej i psychologii wychowawczej) oraz dydaktyki szczegółowej (metodyki nauczania języków obcych) i in. Nieduży zakres przeprowadzonych badań pozwala zaledwie przypuszczać, że braki w odpowiednio zaadaptowanej wiedzy psychopedagogicznej i dydaktycznej, a także w umiejętnościach metodycznych były przyczyną opisanych wyżej niedociągnięć w pracy nauczyciela języków obcych. Jednakże analizując zagadnienie kształcenia nauczycieli języków obcych nie można pominąć poruszonego tu wcześniej problemu jakości kształcenia merytorycznego (kierunkowego).

Przytoczone tu niewielkie dane empiryczne mogły być zaprezentowane tylko w postaci aneksu i jako źródło przykładów. Problem wydaje się jednak ważny i wymaga pogłębionych badań teoretycznych i empirycznych. Niektóre elementy przygotowania zawodowego nauczycieli języków są poza częściowym lub całkowitym zasięgiem bezpośredniego obserwowania. Dlatego dla wzbogacenia i uzupełnienia materiału badawczego uzyskanego metodą obserwacji, należałoby zastosować także inne metody i techniki badań, takie jak analiza dokumentów, czy sondaż diagnostyczny $\mathrm{z}$ zastosowaniem wywiadów z nauczycielami i nadzorującymi ich pracę dyrektorami placówek oświatowych.

\section{Bibliografia}

Bałażak, M. (2009). Wiedza i umiejętności nauczyciela we współczesnej szkole. Radom, Wydawnictwo Politechniki Radomskiej.

Czerepaniak-Walczak, M. (1997). Aspekty i źródła profesjonalnej refleksji nauczyciela. Toruń: Edytor.

Gałązka, A. (2013). Future Learning System. Drama w nauczaniu języka angielskiego. Perspektywa psychopedagogiczna. Katowice, Wydawnictwo UŚ.

Gołębniak B.D., Krzychała, K. (2015). Akademickie kształcenie nauczycieli w Polsce raport z badań. Rocznik Pedagogiczny 38, 97-112.

Gołębniak, B.D., Zamorska, B. (2014). Nowy profesjonalizm nauczycieli. Podejścia praktyka-przestrzeń rozwoju. Wrocław DSW. 
Jakóbowski, J. (1982). Programowanie czynności pedagogicznych u kandydatów na nauczycieli. Bydgoszcz: BTN.

Kawecki, I. (2013). Wiedza i umiejętności początkującego nauczyciela w świetle poglądów Lindy Darling-Hammond, Debata Edukacyjna 6, 89-96.

Komorowska, H. (2017). Kształcenie językowe w Polsce. Warszawa: Wyd. Fundacja Rozwoju Systemu Edukacji.

Komorowska, H. (2015). Rozwój glottodydaktyki a kształcenie nauczycieli języków obcych, Postscriptum Polonistyczne 2, 11-29.

Komorowska, H. (2014). Metodyka nauczania języków obcych. Warszawa: Fraszka Edukacyjna.

Komorowska, H. (1987). Sukces i niepowodzenie w nauce języków obcych. Warszawa: WSiP.

Komorowska, H. (1982). Metody badań empirycznych w glottodydaktyce. Warszawa: PWN.

Kotarbiński, T. (1970). O naukach pedagogicznych, Studia Pedagogiczne 19.

Król, H., Pielachowski, J. (1995), Nauczyciel i jego warsztat pracy. Poznań: Wyd. eMPi2.

Łaszczyk, J.(red.) (2018) Raport: System kształcenia nauczycieli w Polsce - stan i kierunki reformowania. (s. 1-22) Warszawa: RGNiSzW.

Orchowska, I. (2010). Konstruowanie projektu pracy dyplomowej jako element kształcenia akademickiego przyszłych nauczycieli języków obcych, Neofilolog 34, 111-123.

Rozporządzenie Ministra Nauki i Szkolnictwa Wyższego z dnia 25 lipca 2019 r. w sprawie standardu kształcenia przygotowującego do wykonywania zawodu nauczyciela, Zał. nr 1, DZ.U. 2019, Poz.1450.

Rutkowiak, J. (1986). Metodologiczna sytuacja pedagogiki, a modele kształcenia nauczycieli, cz. I, Ruch Pedagogiczny 3, 25-39, cz. II i III, Ruch Pedagogiczny 5-6, 5-23.

Rutkowiak, J. (1994). Teacher training - between atomism and holism. Hult, H. (Eds.), Teacher training and the educational system in Poland (pp. 7-19) Linkoping: Linkoping University Press.

Rutkowiak, J. (1990). „Praktyka” versus „praktyczność” a zagadnienie kształcenia nauczycieli. Przegląd Oświatowo-Wychowawczy 1, 92-98.

Siemak-Tylikowska, A., Kwiatkowska, H., Kwiatkowski, S. (Red.) (1998). Edukacja nauczycielska $w$ perspektywie wymagań zmieniającego się świata. Warszawa: Żak.

Strykowski, W. (2005), Kompetencje współczesnego nauczyciela, Neodidagmata 2005, $27 / 28,15-28$.

Sylwestrowicz, J. (1985). Lekcja języka obcego. Warszawa: WSiP.

Zawadzka, B. (2004). Nauczyciel języków obcych w dobie przemian. Kraków: Impuls. 
